\title{
Near-infrared Spectroscopy in Cerebral Oxygenation Monitoring in Full-term Neonates During Transition: Prospective Cohort Study
}

Marwa Farag ( $\nabla$ d.marwa.farag@gmail.com )

Alexandria University Faculty of Medicine https://orcid.org/0000-0003-0426-9018

Hesham Ghazal

Alexandria University

Alaa Ibrahim

Alexandria University

Mohammed Khalifa

Alexandria University

Bahaa Hammad

Alexandria University

Research Article

Keywords: cSO2, FTEO2, centile charts, transition, NIRS, mode of delivery

Posted Date: February 3rd, 2022

DOI: https://doi.org/10.21203/rs.3.rs-1229223/v1

License: (c) (1) This work is licensed under a Creative Commons Attribution 4.0 International License.

Read Full License 


\section{Abstract}

\section{Background}

Brain is the most important organ in resuscitation. NIRS-measured cerebral oxygenation is evolving brain monitoring tool for neonatal resuscitation.

Method

We undertook a prospective observational study for monitoring of cerebral oxygenation and peripheral preductal saturation at 1,5 and 10 minutes after birth to establish centile chart normative for monitoring of full term neonates during transition. Fractional tissue oxygen extraction was calculated as well. In addition to studying factors affecting cerebral oxygenation at those points in time.

Results

60 healthy term neonates were enrolled to define reference ranges and centile charts of cerebral oxygenation at 1,5, and 10 minutes after birth. The strongest correlations between cerebral oxygenation metrics and peripheral preductal saturation were at 5 minutes after birth. The most significant factor affecting NIRS-measured crSO2 in healthy full term neonates was mode of delivery. This work was registered in the cinicaltrial.gov NCT05158881.

\section{Conclusions}

Normal references of cerebral oxygenation metrics can be used to guide intervention during neonatal resuscitation. Caesarean section is the most significant factor affecting cerebral oxygenation during the transition of healthy full term neonates.

\section{Introduction}

Fetal to neonatal transition is a very complex physiological adaptation that occurs in human experience. Disturbances can occur during transition with potentiality for longer term harm. ${ }^{(1)}$ Clinical assessment of neonates using Apgar score has high inter-observer variability. ${ }^{(2)}$

There are controversies over the effects on short and long term outcome after neonatal resuscitation

using first 10 minutes ranges of $\mathrm{SpO} \otimes$ as it does not provide information about oxygen tissue delivery. ${ }^{(3,4)}$ The brain is a vulnerable organ during fetal to neonatal transition. Routine monitoring using $\mathrm{SpO} \otimes$ and the heart rate does not reflect cerebral oxygenation, perfusion or brain activity. Monitoring cerebral oxygenation may influence interventions which can affect survival, as short- and long-term neurodevelopment outcomes. ${ }^{(5)}$

Cerebral regional oxygen (crSO2) measured via NIRS represents a mixed tissue saturation value, thus enabling information on the balance of cerebral oxygen delivery and oxygen consumption. ${ }^{(1)}$ 
Aim to establish normative in cerebral oxygenation measures, FTEO and cRSO2 using centile charts as well as studying different factors affecting those metrics.

\section{Method}

The present study was held at delivery rooms of the Alexandria University Maternity Hospital (AUMH) from December 2020 till August 2021. Sixty-nine full term neonates with gestational age $(G A) \geq 38$ weeks, without any medical support and normal pregnancy development were enrolled in this study. Thirty patients are born through cesarean section and the other 30 are born vaginally. Nine cases were excluded during the first 10 minutes; 4 cases needed an oxygen supply, 3 cases needed a respiratory support after resuscitating, 2 cases needed positive pressure ventilation during resuscitation. eFigure 1

Patients with perinatal asphyxia, intrauterine growth restriction, Birth complications (e.g. vacuum extraction or forceps application), Suspected or known brain and/ or cardiac malformations and those who need respiratory support or oxygen therapy in the first 10 minutes of life were excluded from the study.

Measurements of crSO2 were recorded using NIRS (INVOSTM 5100C Cerebral/ Somatic Oximeter Monitor; Covidien) by placing a neonatal brain sensor on the left fronto-parietal area of the newborn's head. The regional oxygen saturation was stored every second, over 10 seconds, at end of 1, 5, and 10 minutes after birth.

The FTOE were calculated during the first 10 minutes of life with the following formula: FTOE $=($ SpO2$\mathrm{crSO} 2) / \mathrm{SpO} 2$. At the same time, Sp02were measured using pulse oximeter (Masimo or Nellcor) by applying a preductal pulse oximetry sensor to the right wrist. Venus blood gas samples were obtained from umbilical cord blood of all neonates and clinical status were assessed by Apgar score at 1, 5 and 10minutes of life. Informed parental consents were obtained for all enrolled newborns and the criteria for the ethical committee of the faculty of medicine in Alexandria University were strictly applied.

Data were fed to the computer and analyzed using IBM SPSS software package version 20.0. The Kolmogorov-Smirnov test was used to verify the normality of distribution. Qualitative data were described using number and percent. Quantitative data were described using range (minimum and maximum), mean, standard deviation, median, interquartile range (IQR) and percentiles. The centiles (10th, 25th, 50th, 75th and 90th) for the cTOI and cFTOE were calculated using the least mean square (LMS) method described by Cole and Green. For categorical variables, chi-squared and fisher's exact tests were used to compare between different groups. To compare between two independent studied groups, student t-test and mann whitney test were used for both normally and abnormally distributed quantitative variables, respectively. Univariate and multivariate binary logistic regression analysis were constructed to identify independent risk factors (predictors) for low and high CrSo2 norms (below and above 50th centile values). Pearson and spearman correlations coefficients were used to correlate normally and abnormally distributed quantitative variables, respectively. Significance of the obtained results was judged at the $5 \%$ level. 


\section{Results}

Table (1) show descriptive analysis of the studied cases according to demographic data (sex, GA, weight and mode of delivery), resuscitation needs, APGAR score, venous cord blood gases and clinical parameters (Heart rate at 10 minutes, CRT, preductal oxygen saturation at 1,5 and 10 minutes)

There are significant positive correlations between cerebral tissue oxygenation and preductal oxygen saturation (pulse oximeter) at 1,5 , and 10 minutes with r $0.532 *, r 0.73$, and r 0.34 , respectively, Figure 2 . Whereas, there are significant negative correlations between fractional tissue extraction and preductal oxygen saturation (pulse oximeter) at 1,5 , and 10 minutes with $r=0.532^{\star}, r=0.73$, and $r=0.34$, respectively.

Table (2) and figure 1: show centile (5th,25th,50th,75th,90th ) charts for cRsO2 and FTEO at 1, 5 and 10 minutes after birth in healthy full term neonates Fifth centile was used to classify patients into low norms and high norms.

Univariate and multivariate logistic regression analysis for the predictors of low normal and high normal cerebral tissue oxygenation at 1,5 , and 10 minutes,Table3. The most significant factor affecting cerebral oxygenation at 5 and 10 minutes is the mode of delivery. Infants born by cesarean section have significantly higher SPO2 and crSO2, and significantly lower FTOE at 5 and 10 minutes after birth.

Despite no significant difference in cerebral oxygenation metrics and SPO2 between infants born by Cs or vaginally in the first 1 minute after birth, the rate of rise from 1st to 5 minutes was significantly higher in infants born vaginally.

\section{Discussion}

The NIRS technology is approximately 45 years old and there is an increasing interest to use NIRS in the first few minutes after birth. NIRS-measured $\mathrm{CrSO}$ and preductal SpO2 monitoring can guide oxygen supply and the medical support during neonatal transition. ${ }^{(1)}$ Cerebral regional oxygen saturation values can be maintained between 10th and 90th centile, thus preventing hypoxic and hyperoxic brain injury. ${ }^{(6)}$

The first prerequisite for use of NIRS as a guide for intervention needs during resuscitation is establishing normal ranges for regional oxygenation metrics in first 10 minutes after birth.

Cerebral regional oxygen saturation (crSO 8 ) reading was obtained within the first minute of life and gradually increased through the first 10 minutes and in contrast cerebral fractional oxygen extraction

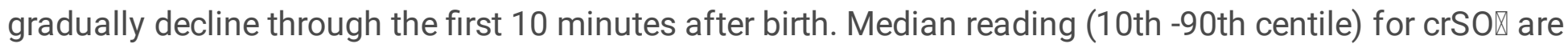
$44.5 \%(19.6-64)$ at 1 minute, $72.5 \%(57-82.9)$ at 5 minutes and $83 \%(72-89)$ at 10 minutes while median vaues (10th -90th centile ). For cFTOE measure are $0.44(0.18-0.73)$ at 1 minute, at 5 minutes $0.18(0,1-$ 0,35 ) and at 10 minutes $0.13(0.07-0.25)$. 


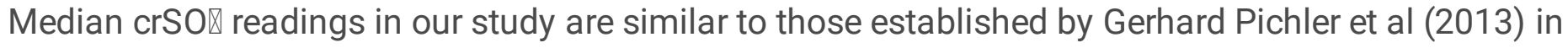
term neonates who did not need a respiratory support with NIRS device (INVOS 5100). Median readings obtained in their study were $41 \%(23-64)$ at 2 minutes, 68\% (45-85) at 5 minutes and $79 \%(65-90)$ at 10 minutes. ${ }^{(7)}$

Nastase L study (2017) used the same criteria with the same NIRS device ( INVOS 5100) and median crSO $\triangle$ readings were $35 \%(15-58.2)$ at 1 minute, 64\%(46.2-85) at 5 minutes and 76\% (67.6-87.4) at 10 minutes. ${ }^{(8)}$ Higher 1 minute readings of $\mathrm{crSO} \bigotimes$ in our study might be attributed to maternal exposure to $40 \%$ oxygen through face mask during cesarean section and this was not mentioned in Nastase $L$ study.

Ranges of crSO $\triangle$ may vary according to several factors such as the NIRS device used, gestational age, and need for respiratory support. Cerebral oxygenation measures vary according to the used NIRS devices as the calculated values are determined by different algorithms used by competing vendors. ${ }^{(6)}$ Brain oxygenation metrics are higher among the preterm infants and this is mostly due to impaired cerebral autoregulation in preterm neonates and the different ability of brain tissue to extract oxygen as explained by Lucia Gabriella (2009). ${ }^{(9)}$ Also neonates who need respiratory support have a compromised cerebral tissue oxygenation compared to those without disturbed transition. This difference indicates that

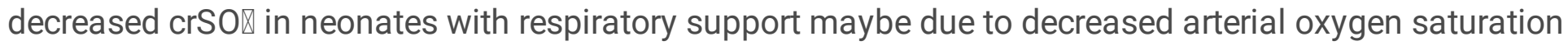
levels and compromised perfusion as found by Schwaberger B (2014). ${ }^{(10)}$ Those factors won't affect readings in the current work as we included only healthy, full term neonates monitored with the same device. In order to discover other factors that might affect cerebral oxygenation in healthy full term neonates we used 50th centile values to divide patients into high and low norms. Then we constructed logestic regression models to discover the significant predictors of low and high norms. The only significant factor was the mode of delivery at 5 and 10 minutes. Therefore, we divided the patients into Csection and NVD groups and compared them as regard different clinical and oxygenation parameters.

Preductal Oxygen saturation (SpOQ) measures were compared at 1, 5 and 10 minutes of life in patient delivered vaginally or by cesarean section table 5. Oxygen saturation at the first minute showed no statically significant difference between the 2 studied groups $(p=0.146)$. This might be attributed to

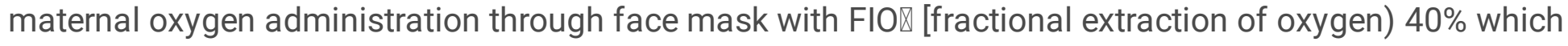

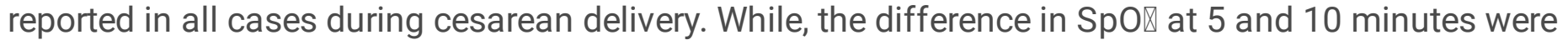
statically significant between the normal vaginal and the cesarean groups $(p=0.001, p=0.031$ respectively). This is might be secondary to the delayed clearance of fetal lung fluid during cesarean delivery. ${ }^{(11)}$

Regional cerebral oxygenation (crSO $\nabla$ ) was recorded during the first 10 minutes of life simultaneously with peripheral arterial oxygen saturation through pulse oximeter. Table (5) showed NIRS readings for crSO $\triangle$ at 1,5 and 10 minutes of life and compared between the patients delivered by CS and NVD. Several studies were different regarding the effect of the mode of delivery on crSO凶. $(8,12,13)$ In the present study,

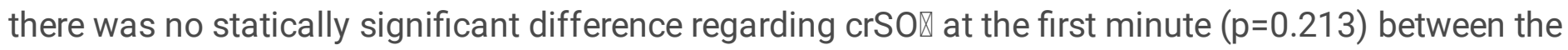
normal vaginal and the cesarean groups in contrast to Nastase L et al (2017) study. ${ }^{(8)}$ This might be 
attributed to maternal administration of oxygen through face mask during cesarean section which may raise fetal oxygen saturation at birth. Reginal oxygenation metrics (CrSO 8 ) at 5 and 10 minutes showed statically significant difference between the patients in patient delivered vaginally or by cesarean section. Average crSO reading of normal vaginal group at 5 minutes was $74.67 \%$ vs $66.37 \%$ in the cesarean group ( $p=0.001$ ) while average NVD group reading at 10 minutes was $84.13 \%$ vs $78.37 \%$ in the CS group ( $p=0.001)$ similarly found by Nastase $L$ et al (2017) and in contrast to Gerhard Pichler et al (2013) and Berndt Urlesberge et al $(2011) .{ }^{(13,14)}$ The rate of rise from 1 to 5 minutes of life was statically significantly higher among the vaginal group $(36 \%)$ than the cesarean group $(22 \%)$ with $p<0.001$.

FTOE indicates an increase of oxygen consumption due to increased cerebral metabolic rate, decreased oxygen delivery or both. ${ }^{(15)}$ Fractional tissue oxygen extraction at 1,5 and 10 minutes were calculated and compared between the patients delivered vaginally or by cesarean section. Despite crSO $\mathrm{W}$ was not different in the 2 groups, FTOE at 1 minute showed a near significant difference between the 2 groups with median value (0.38) in the cesarean group and $(0.52)$ in the normal vaginal group $(p=0.07$ in patient delivered vaginally or by cesarean section, respectively. FTOE considerably decreased at 5 and 10 minutes and showed statically significant difference between the 2 groups $(p=0.005, p=0.004$ respectively), in agreement with Nastase L study (2017). ${ }^{(8)}$

Better cerebral oxygenation metrics and preductal peripheral oxygen saturation were found in vaginal than cesarean group that might be attributed to higher cerebral blood flow due to higher level of carbon dioxide which is the most potent cerebral vasodilator. ${ }^{(8)}$ Another contributing factor is that the vaginally delivered newborns showed a significantly higher catecholamine levels at birth in comparison with those born by cesarean section as found by Kenichi Isobe et al (2002). ${ }^{(16)}$ Released catecholamines act to constrict the peripheral vessels thus increasing the cerebral blood flow. In addition, there is more rapid clearance of fetal lung fluids in the normal vaginal group.

It is logic that there must be correlation between SPO2 and cerebral oxygenation parameters (crSO2 and FTEO). However, their relationship is not constant at 1,5 and 10 minutes. The most significant correlations were at 5 minutes SPO2 and cerebra oxygenation parameters (crSO2 and FTEO) with r=0.6 and $r=0.4$, respectively.

The discrepancy in the strength of correlation could be explained by the following factors: first; crSOQ reaches the plateau earlier than the peripheral arterial saturation ( $\mathrm{SpO} \otimes)$ and the preferential oxygen delivery to the brain during the first few minutes after birth. ${ }^{(15)}$ Second; the cerebral vascular bed constricts after 5 minutes in response to the postnatal rise in the blood oxygen content to protect the brain from excessive oxygen exposure.third; Kehrer $\mathrm{M}$ et al (2005) suggested by that the increasing left-toright shunt through the patent ductus arteriosus together with an inadequate compensatory increase in left ventricular output might decrease the cerebral blood flow (17) $^{(17}$

The limitations of this work is the small sample size the major point of strength that it is the only known published data and centiles abut NIRS monitoring in neonatal transition from developing countries. 


\section{Conclusions}

NIRS-measured crSO2 guided by centile charts become the most promising method which provides feasible rapid continuous non-invasive monitoring and quantification of cerebral oxygenation during resuscitation. It might influence interventions needs during resuscitation and might be a predictor for short- and long-term outcome. The most significant factor affecting NIRS-measured crSO2 in healthy full term neonates is the mode of delivery.

\section{Declarations}

\section{Consent for publication}

Informed consent was obtained from parents or authorized legal representatives of all newborns who participated in the study for publication of anonymous patients' data.

\section{Availability of data and material (data transparency)}

The datasets generated during and/or analyzed during the current study are available from the corresponding author on reasonable request

\section{Ethics-approval and consent to participate}

The study protocol has been approved by the Research Ethics Committee of Alexandria faculty of medicine. Approval no. is 0106540 in 17-9-2020 (date of approval). IRB no. is 00012098 and FWA no. is 00018699. Written informed consent was obtained from parents or authorized legal representatives of all newborns who participated in the study for publication of anonymous patients' data.

\section{Competing interests Statement}

The authors have no conflicts of interest to declare.

\section{Funding Sources}

This research did not receive any specific grant from funding agencies in the public, commercial, or notfor-profit sectors.

\section{Acknowledgement}

We are grateful and thankful all the patients, parents and staff of the NICU of Alexandria university that participated in the study.

\section{Authors' contributions}

Hesham Abd EL-Rahim Ghazal conceived of the presented idea. 
Bahaa Salah-El Din Hammad, Alaa Ibrahim and Marwa M. Farag worked out all of the technical and medical details.

Alaa Ibrahim collected the data.

Mohammed Khalifa, Marwa M. Farag, and Alaa Ibrahim verified the analytical methods.

Alaa Ibrahim, Marwa Farag, Bahaa Salah-El Din Hammad, and Mohammed Khalifa contributed in interpretation of results.

Marwa Farag and Alaa Ibrahim wrote the first draft of the manuscript.

Hesham Abd EL-Rahim Ghazal supervised the findings of this work.

All authors provided critical feedback and helped shape the research, analysis and approved the final version of the manuscript.

\section{References}

1. Marlies B, Gerhard P, Berndt U, et al. NIRS in the fetal to neonatal transition and immediate postnatal period. Semin Fetal Neonatal Med. 2020; 25(2):101079.

2. Bashambu MT, Whitehead H V, Hibbs A M, Martin R J \& Bhola M Evaluation of Interobserver Agreement of Apgar Scoring in Preterm Infants. (2012). Pediatrics. 130. e982-7.

3. Kapadia VS, Lal CV, Kakkilaya V, Heyne R, Savani RC, Wyckoff MH. Impact of the Neonatal Resuscitation Program-Recommended Low Oxygen Strategy on Outcomes of Infants Born Preterm. J Pediatr. 2017;191:35-41. doi:10.1016/j.jpeds.2017.08.074

4. Pichler G, Cheung P-Y, Aziz K, Urlesberger B, Schm.Izer GM. How to Monitor the Brain during Immediate Neonatal Transition and Resuscitation: A Systematic Qualitative Review of the Literature. Neonatology. 2014;105(3):205-10.

5. Wolf M, Greisen G. Advances in near-infrared spectroscopy to study the brain of the preterm and term neonate. Clin Perinatol. 2009;36(4):807-34.

6. Pichler G, Schmölzer GM, Urlesberger B. Cerebral Tissue Oxygenation during Immediate Neonatal Transition and Resuscitation. Front Pediatr. 2017;5:29. Published 2017 Feb 23. doi:10.3389/fped.2017.00029

7. Pichler G, Binder C, Avian A, Beckenbach E, Schmölzer GM, Urlesberger B. Reference ranges for regional cerebral tissue oxygen saturation and fractional oxygen extraction in neonates during immediate transition after birth. J Pediatr. 2013;163(6):1558-63.

8. Nastase L, Stoicescu SM, Banceanu G. Cerebral regional oxygen saturation of the neonate during the transition to extrauterine life. Obstet Ginecol 2017(6):235-40.

9. Tina LG, Frigiola A, Abella R, Artale B, Puleo G, D'Angelo S, et al. Near infrared spectroscopy in healthy preterm and term newborns: correlation with gestational age and standard monitoring parameters. 
2009;6(3):148-54.

10. Schwaberger B, Pichler G, Binder C, Avian A, Pocivalnik M, Urlesberger BJPm. Even mild respiratory distress alters tissue oxygenation significantly in preterm infants during neonatal transition. 2014;35(10):2085.

11. Rabi Y, Yee W, Chen SY, Singhal N. Oxygen saturation trends immediately after birth. J Pediatr. 2006 May;148(5):590-4.

12. Baik N, Urlesberger B, Schwaberger B, Schmölzer GM, Mileder L, Avian A, Pichler G. Reference Ranges for Cerebral Tissue Oxygen Saturation Index in Term Neonates during Immediate Neonatal Transition after Birth. Neonatology. 2015;108(4):283-6.

13. Pichler G, Binder C, Avian A, Beckenbach E, Schmölzer GM, Urlesberger B. Reference ranges for regional cerebral tissue oxygen saturation and fractional oxygen extraction in neonates during immediate transition after birth. J Pediatr. 2013;163(6):1558-63.

14. Urlesberger B, Kratky E, Rehak T, Pocivalnik M, Avian A, Czihak J, et al. Regional oxygen saturation of the brain during birth transition of term infants: comparison between elective cesarean and vaginal deliveries. J Pediatr. 2011;159(3):404-8.

15. Urlesberger B, Grossauer K, Pocivalnik M, Avian A, Müller W, Pichler GJTJop. Regional oxygen saturation of the brain and peripheral tissue during birth transition of term infants. 2010;157(5):7404.

16. Isobe K, Kusaka T, Fujikawa Y, Okubo K, Nagano K, Yasuda S, Kondo M, Itoh S, Hirao K, Onishi S. Measurement of cerebral oxygenation in neonates after vaginal delivery and cesarean section using full-spectrum near infrared spectroscopy. Comp Biochem Physiol A Mol Integr Physiol. 2002 May;132(1):133-8. doi: 10.1016/s1095-6433(01)00539-6. PMID: 12062201.

17. Kehrer M, Blumenstock G, Ehehalt S, Goelz R, Poets C, Schöning M. Development of cerebral blood flow volume in preterm neonates during the first two weeks of life. Pediatr Res. 2005 Nov;58(5):92730. doi: 10.1203/01.PDR.0000182579.52820.C3. Epub 2005 Sep 23. PMID: 16183816.

\section{Tables}

Table (1): Descriptive analysis of the studied cases according to demographic, resuscitation, venous cord blood gases and clinical parameters 


\begin{tabular}{|c|c|c|}
\hline & Studied cases $(n=60)$ & Percent \\
\hline \multicolumn{3}{|l|}{ Gender } \\
\hline Male & 31 & $51.7 \%$ \\
\hline Female & 29 & $48.3 \%$ \\
\hline \multicolumn{3}{|c|}{ Mode of delivery } \\
\hline $\mathrm{CS}$ & 30 & $50 \%$ \\
\hline NVD & 30 & $50 \%$ \\
\hline \multicolumn{3}{|l|}{ GA } \\
\hline Min. - Max & $38.0-41.0$ & \\
\hline Mean \pm SD. & $38.67 \pm 0.71$ & \\
\hline Median (IQR) & $39.0(38.0-39.0)$ & \\
\hline \multicolumn{3}{|l|}{ BWT } \\
\hline Min. - Max & $2.70-3.80$ & \\
\hline Mean \pm SD. & $3.18 \pm 0.28$ & \\
\hline Median (IQR) & $3.20(2.95-3.40)$ & \\
\hline \multicolumn{3}{|l|}{ Resuscitation } \\
\hline Routine care & 39 & $65.0 \%$ \\
\hline Initial steps & 21 & $35.0 \%$ \\
\hline \multicolumn{3}{|c|}{ Apgar at $1 \mathrm{~min}$} \\
\hline Min. - Max & $6.00-8.00$ & \\
\hline Mean \pm SD. & $6.92 \pm 0.59$ & \\
\hline Median (IQR) & $7.00(7.00-7.00)$ & \\
\hline \multicolumn{3}{|l|}{ Apgar at $5 \mathrm{~min}$} \\
\hline Min. - Max & $8.00-10.00$ & \\
\hline Mean \pm SD. & $9.32 \pm 0.60$ & \\
\hline Median (IQR) & $9.00(9.00-10.00)$ & \\
\hline \multicolumn{3}{|c|}{ Venous cord blood gases } \\
\hline \multicolumn{3}{|l|}{$\mathrm{PH}$} \\
\hline Min. - Max & $7.11-7.45$ & \\
\hline
\end{tabular}




\begin{tabular}{|c|c|}
\hline Mean \pm SD. & $7.30 \pm 0.08$ \\
\hline Median (IQR) & $7.32(7.24-7.36)$ \\
\hline \multicolumn{2}{|l|}{ PCO2 mmhg } \\
\hline Min. - Max & $20.10-74.20$ \\
\hline Mean \pm SD & $48.81 \pm 10.61$ \\
\hline Median (IQR) & $50.30(41.45-55.35)$ \\
\hline \multicolumn{2}{|l|}{$\mathrm{HCO} 3 \mathrm{mmol} / \mathrm{L}$} \\
\hline Min. - Max & $11.20-29.30$ \\
\hline Mean \pm SD & $23.49 \pm 3.75$ \\
\hline Median (IQR) & $24.00(22.00-25.90)$ \\
\hline \multicolumn{2}{|l|}{ BE } \\
\hline Min. - Max & $-18.30-4.00$ \\
\hline Mean \pm SD. & $-2.70 \pm 4.24$ \\
\hline Median (IQR) & $-2.10(-4.55--0.05)$ \\
\hline \multicolumn{2}{|l|}{$\mathrm{HR} \mathrm{b} / \mathrm{min}$} \\
\hline Min. - Max & $110.0-160.0$ \\
\hline Mean \pm SD. & $137.3 \pm 12.3$ \\
\hline Median (IQR) & $138.0(128.0-146.5)$ \\
\hline \multicolumn{2}{|l|}{ CRT second } \\
\hline Min. - Max & $2.0-4.0$ \\
\hline Mean \pm SD. & $2.33 \pm 0.51$ \\
\hline Median (IQR) & $2.0(2.0-3.0)$ \\
\hline \multicolumn{2}{|c|}{ Oxygen saturation \% } \\
\hline \multicolumn{2}{|l|}{$\mathrm{SpO} 2$ at $1 \mathrm{~min}$} \\
\hline Min. - Max & $65.0-89.0$ \\
\hline Mean \pm SD. & $74.62 \pm 6.48$ \\
\hline Median (IQR) & $75.0(70.0-79.0)$ \\
\hline \multicolumn{2}{|l|}{$\mathrm{SpO} 2$ at $5 \mathrm{~min}$} \\
\hline Min. - Max & $83.0-99.0$ \\
\hline
\end{tabular}




\begin{tabular}{|ll|} 
Mean \pm SD. & $89.30 \pm 3.73$ \\
\hline Median (IQR) & $89.0(86.0-92.0)$ \\
\hline Min. - Max 10 min & $91.0-100.0$ \\
Mean \pm SD. & $96.07 \pm 2.17$ \\
Median (IQR) & $96.0(94.0-98.0)$ \\
\hline
\end{tabular}

Table (2): Descriptive analysis of the studied cases according to cerebral tissue oxygenation and fractional tissue extraction

\begin{tabular}{|c|c|c|c|c|c|c|c|}
\hline & & NIRS 1 & NIRS 5 & NIRS 10 & FTOE 1 & FTOE 5 & FTOE 10 \\
\hline \multicolumn{2}{|l|}{ Mean } & 42.13 & 70.52 & 81.25 & 0.4413 & 0.2120 & 0.1544 \\
\hline \multicolumn{2}{|l|}{ Median } & 44.50 & 72.50 & 83.00 & 0.4495 & 0.1848 & 0.1327 \\
\hline \multicolumn{2}{|l|}{ Minimum } & 15 & 41 & 60 & 0.0000 & 0.0581 & 0.0625 \\
\hline \multicolumn{2}{|l|}{ Maximum } & 78 & 86 & 91 & 0.7917 & 0.5233 & 0.3673 \\
\hline \multirow[t]{5}{*}{ Percentiles } & 10 & 19.60 & 57.00 & 72.00 & 0.1885 & 0.1055 & 0.0751 \\
\hline & 25 & 30.00 & 62.00 & 78.00 & 0.2999 & 0.1304 & 0.1061 \\
\hline & 50 & 44.50 & 72.50 & 83.00 & 0.4495 & 0.1848 & 0.1327 \\
\hline & 75 & 53.50 & 80.00 & 87.00 & 0.5741 & 0.3014 & 0.1804 \\
\hline & 90 & 64.00 & 82.90 & 89.00 & 0.7304 & 0.3519 & 0.2575 \\
\hline
\end{tabular}

Table (3a, b, and c): Univariate and multivariate logistic regression analysis for the parameters affecting cerebral tissue oxygenation at 1,5 and 10 minutes, respectively. 


\begin{tabular}{|c|c|c|c|c|c|c|}
\hline & \multicolumn{2}{|l|}{ NIRS at $1 \mathrm{~min}$} & \multicolumn{2}{|c|}{ Univariate } & \multicolumn{2}{|c|}{ \#Multivariate } \\
\hline & $\begin{array}{l}\text { Low Normal } \\
(n=30)\end{array}$ & $\begin{array}{l}\text { High Normal } \\
(n=30)\end{array}$ & $\mathrm{p}$ & OR (95\%C.I) & 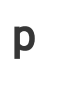 & $\begin{array}{l}\text { OR } \\
\text { (95\%C.I) }\end{array}$ \\
\hline \multicolumn{7}{|l|}{$\begin{array}{l}\text { Cord Blood } \\
\text { Gases }\end{array}$} \\
\hline \multicolumn{7}{|l|}{$\mathrm{Ph}$} \\
\hline Min. - Max. & $7.11-7.45$ & $7.19-7.44$ & \multirow[t]{3}{*}{0.962} & \multirow{3}{*}{$\begin{array}{l}0.985(0.532- \\
1.826)\end{array}$} & & \\
\hline Mean \pm SD. & $7.30 \pm 0.09$ & $7.30 \pm 0.07$ & & & & \\
\hline Median (IQR) & $\begin{array}{l}7.33(7.25- \\
7.37)\end{array}$ & $\begin{array}{l}7.31(7.24- \\
7.35)\end{array}$ & & & & \\
\hline \multicolumn{7}{|l|}{ PCO2 } \\
\hline Min. - Max. & $32.70-74.20$ & $20.10-66.60$ & \multirow[t]{3}{*}{0.587} & \multirow{3}{*}{$\begin{array}{l}1.014(0.966- \\
1.064)\end{array}$} & & \\
\hline Mean \pm SD. & $48.07 \pm 10.45$ & $49.54 \pm 10.88$ & & & & \\
\hline Median (IQR) & $\begin{array}{l}48.00(40.00- \\
53.00)\end{array}$ & $\begin{array}{l}51.55(42.10- \\
57.70)\end{array}$ & & & & \\
\hline \multicolumn{7}{|l|}{$\mathrm{HCO} 3$} \\
\hline Min. - Max. & $11.20-29.30$ & $13.40-28.80$ & \multirow[t]{3}{*}{0.811} & \multirow{3}{*}{$\begin{array}{l}1.017(0.887- \\
1.165)\end{array}$} & & \\
\hline Mean \pm SD. & $23.37 \pm 3.78$ & $23.60 \pm 3.78$ & & & & \\
\hline Median (IQR) & $\begin{array}{l}23.95(21.50- \\
25.60)\end{array}$ & $\begin{array}{l}24.10(23.00- \\
26.00)\end{array}$ & & & & \\
\hline \multicolumn{7}{|l|}{ BE } \\
\hline Min. - Max. & $-18.30-4.00$ & $-14.00-3.00$ & \multirow[t]{3}{*}{0.729} & \multirow{3}{*}{$\begin{array}{l}1.022(0.905- \\
1.153)\end{array}$} & & \\
\hline Mean \pm SD. & $-2.89 \pm 4.72$ & $-2.51 \pm 3.76$ & & & & \\
\hline Median (IQR) & $\begin{array}{l}-2.10(-5.50- \\
1.00)\end{array}$ & $\begin{array}{l}-2.15(-3.50- \\
-0.40)\end{array}$ & & & & \\
\hline \multicolumn{7}{|l|}{$\begin{array}{l}\text { Mode of } \\
\text { Delivery }\end{array}$} \\
\hline Cs & $14(46.7 \%)$ & $16(53.3 \%)$ & \multirow[t]{2}{*}{0.606} & 1.000 & & \\
\hline NVD & $16(53.3 \%)$ & $14(46.7 \%)$ & & $\begin{array}{l}0.766(0.278- \\
2.111)\end{array}$ & & \\
\hline \multicolumn{7}{|l|}{$\begin{array}{l}\text { Maternal } \\
\text { history }\end{array}$} \\
\hline Anemia & $16(53.3 \%)$ & 20 (66.7\%) & 0.294 & $\begin{array}{l}1.750(0.616- \\
4.973)\end{array}$ & & \\
\hline
\end{tabular}




\begin{tabular}{|lllll|} 
PIH & $4(13.3 \%)$ & $4(13.3 \%)$ & 0.999 & $\begin{array}{l}1.000(0.226- \\
4.431)\end{array}$ \\
\hline UTI & $12(40.0 \%)$ & $7(23.3 \%)$ & 0.169 & $\begin{array}{l}0.457(0.149- \\
1.396)\end{array}$ \\
& & & & $1.306(0.474-$ \\
Vaginitis & $14(46.7 \%)$ & $16(53.3 \%)$ & 0.606 & $3.602)$ \\
\hline
\end{tabular}

IQR: Inter quartile range SD: Standard deviation OR: Odd`s ratio

C.I: Confidence interval LL: Lower limit UL: Upper Limit

$p: p$ value for Odd`s ratio for comparing between the studied groups

*: Statistically significant at $p \leq 0.05$

\#: All variables with $p<0.05$ in Univariate was included in the multivariate 


\begin{tabular}{|c|c|c|c|c|c|c|}
\hline & \multicolumn{2}{|l|}{ NIRS at $5 \mathrm{~min}$} & \multicolumn{2}{|c|}{ Univariate } & \multicolumn{2}{|c|}{ \#Multivariate } \\
\hline & $\begin{array}{l}\text { Low Normal } \\
(n=30)\end{array}$ & $\begin{array}{l}\text { High Normal } \\
(n=30)\end{array}$ & $p$ & OR (95\%C.I) & $p$ & OR (95\%C.I) \\
\hline \multicolumn{7}{|l|}{$\begin{array}{l}\text { Cord Blood } \\
\text { Gases }\end{array}$} \\
\hline \multicolumn{7}{|l|}{$\mathrm{Ph}$} \\
\hline $\begin{array}{l}\text { Min. - } \\
\text { Max. }\end{array}$ & $7.11-7.45$ & $7.16-7.45$ & \multirow[t]{3}{*}{0.626} & \multirow[t]{3}{*}{$\begin{array}{l}1.167(0.627- \\
2.169)\end{array}$} & & \\
\hline Mean \pm SD & $7.30 \pm 0.10$ & $7.31 \pm 0.07$ & & & & \\
\hline $\begin{array}{l}\text { Median } \\
\text { (IQR) }\end{array}$ & $\begin{array}{l}7.32(7.23- \\
7.39)\end{array}$ & $\begin{array}{l}7.32(7.26- \\
7.35)\end{array}$ & & & & \\
\hline \multicolumn{7}{|l|}{$\mathrm{PCO} 2$} \\
\hline $\begin{array}{l}\text { Min. - } \\
\text { Max. }\end{array}$ & $31.60-74.20$ & $20.10-65.00$ & \multirow[t]{3}{*}{0.853} & \multirow[t]{3}{*}{$\begin{array}{l}1.005(0.957- \\
1.054)\end{array}$} & & \\
\hline Mean \pm SD. & $48.55 \pm 10.82$ & $49.06 \pm 10.56$ & & & & \\
\hline $\begin{array}{l}\text { Median } \\
\text { (IQR) }\end{array}$ & $\begin{array}{l}48.00(39.10- \\
53.00)\end{array}$ & $\begin{array}{l}51.30(41.80- \\
57.00)\end{array}$ & & & & \\
\hline \multicolumn{7}{|l|}{$\mathrm{HCO} 3$} \\
\hline $\begin{array}{l}\text { Min. - } \\
\text { Max. }\end{array}$ & $11.20-29.30$ & $13.40-28.80$ & \multirow[t]{3}{*}{0.587} & \multirow[t]{3}{*}{$\begin{array}{l}1.039(0.905- \\
1.192)\end{array}$} & & \\
\hline Mean \pm SD & $23.23 \pm 3.70$ & $23.75 \pm 3.84$ & & & & \\
\hline $\begin{array}{l}\text { Median } \\
\text { (IQR) }\end{array}$ & $\begin{array}{l}23.55(20.90- \\
25.60)\end{array}$ & $\begin{array}{l}24.30(23.40- \\
26.70)\end{array}$ & & & & \\
\hline \multicolumn{7}{|l|}{ BE } \\
\hline $\begin{array}{l}\text { Min. - } \\
\text { Max. }\end{array}$ & $-18.30-4.00$ & $-14.00-3.70$ & \multirow[t]{3}{*}{0.567} & \multirow[t]{3}{*}{$\begin{array}{l}1.036(0.917- \\
1.171)\end{array}$} & & \\
\hline Mean \pm SD. & $-3.01 \pm 4.60$ & $-2.39 \pm 3.89$ & & & & \\
\hline $\begin{array}{l}\text { Median } \\
\text { (IQR) }\end{array}$ & $\begin{array}{l}-2.40(-4.80- \\
-0.40)\end{array}$ & $\begin{array}{l}-2.00(-3.40- \\
0.30)\end{array}$ & & & & \\
\hline \multicolumn{7}{|l|}{$\begin{array}{l}\text { Mode Of } \\
\text { Delivery }\end{array}$} \\
\hline Cs & $20(66.7 \%)$ & $10(33.3 \%)$ & \multirow[t]{2}{*}{$0.011^{*}$} & 1.000 & \multirow[t]{2}{*}{$0.011^{*}$} & 1.000 \\
\hline NVD & $10(33.3 \%)$ & $20(66.7 \%)$ & & $\begin{array}{l}4.000(1.367- \\
11.703)\end{array}$ & & $\begin{array}{l}4.000 \\
(1.367- \\
11.703)\end{array}$ \\
\hline
\end{tabular}




\begin{tabular}{|lllll|}
\hline history & & & & \\
\hline Anemia & $16(53.3 \%)$ & $20(66.7 \%)$ & 0.294 & $\begin{array}{l}1.750(0.616- \\
4.973)\end{array}$ \\
\hline PIH & $4(13.3 \%)$ & $4(13.3 \%)$ & 0.999 & $\begin{array}{l}1.000(0.226- \\
4.431)\end{array}$ \\
\hline UTI & $10(33.3 \%)$ & $9(30.0 \%)$ & 0.781 & $\begin{array}{l}0.857(0.288- \\
2.547)\end{array}$ \\
& & & & $1.306(0.474-$ \\
Vaginitis & $14(46.7 \%)$ & $16(53.3 \%)$ & 0.606 & $3.602)$ \\
\hline
\end{tabular}

IQR: Inter quartile range SD: Standard deviation OR: Odd`s ratio

C.I: Confidence interval LL: Lower limit UL: Upper Limit

$p: p$ value for Odd`s ratio for comparing between the studied groups

*: Statistically significant at $p \leq 0.05$

\#: All variables with $p<0.05$ in Univariate was included in the multivariate 


\begin{tabular}{|c|c|c|c|c|c|c|}
\hline & \multicolumn{2}{|l|}{ NIRS at $10 \mathrm{~min}$} & \multicolumn{2}{|c|}{ Univariate } & \multicolumn{2}{|c|}{ \#Multivariate } \\
\hline & $\begin{array}{l}\text { Low Normal } \\
(n=30)\end{array}$ & $\begin{array}{l}\text { High Normal } \\
(n=30)\end{array}$ & $p$ & OR (95\%C.I) & $p$ & $\begin{array}{l}\text { OR } \\
\text { (95\%C.I) }\end{array}$ \\
\hline \multicolumn{7}{|l|}{$\begin{array}{l}\text { Cord } \\
\text { Blood } \\
\text { Gases }\end{array}$} \\
\hline \multicolumn{7}{|l|}{$\mathrm{Ph}$} \\
\hline $\begin{array}{l}\text { Min. - } \\
\text { Max. }\end{array}$ & $7.11-7.45$ & $7.14-7.45$ & \multirow[t]{3}{*}{0.310} & \multirow[t]{3}{*}{$\begin{array}{l}0.721(0.383 \\
-1.356)\end{array}$} & & \\
\hline $\begin{array}{l}\text { Mean } \pm \\
\text { SD. }\end{array}$ & $7.31 \pm 0.09$ & $7.29 \pm 0.08$ & & & & \\
\hline $\begin{array}{l}\text { Median } \\
\text { (IQR) }\end{array}$ & $\begin{array}{l}7.33(7.27- \\
7.38)\end{array}$ & $\begin{array}{l}7.30(7.24- \\
7.35)\end{array}$ & & & & \\
\hline \multicolumn{7}{|l|}{$\mathrm{PCO} 2$} \\
\hline $\begin{array}{l}\text { Min. - } \\
\text { Max. }\end{array}$ & $31.60-74.20$ & $20.10-65.00$ & \multirow[t]{3}{*}{0.309} & \multirow[t]{3}{*}{$\begin{array}{l}1.026(0.977 \\
-1.078)\end{array}$} & & \\
\hline $\begin{array}{l}\text { Mean } \pm \\
\text { SD. }\end{array}$ & $47.41 \pm 10.98$ & $50.20 \pm 10.21$ & & & & \\
\hline $\begin{array}{l}\text { Median } \\
\text { (IQR) }\end{array}$ & $\begin{array}{l}46.85(37.30- \\
52.00)\end{array}$ & $\begin{array}{l}51.75(42.10- \\
57.00)\end{array}$ & & & & \\
\hline \multicolumn{7}{|l|}{$\mathrm{HCO} 3$} \\
\hline $\begin{array}{l}\text { Min. - } \\
\text { Max. }\end{array}$ & $11.20-29.30$ & $13.40-28.80$ & \multirow[t]{3}{*}{0.737} & \multirow[t]{3}{*}{$\begin{array}{l}1.024(0.893 \\
-1.174)\end{array}$} & & \\
\hline $\begin{array}{l}\text { Mean } \pm \\
\text { SD. }\end{array}$ & $23.33 \pm 3.71$ & $23.65 \pm 3.85$ & & & & \\
\hline $\begin{array}{l}\text { Median } \\
\text { (IQR) }\end{array}$ & $\begin{array}{l}24.00(22.30- \\
25.50)\end{array}$ & $\begin{array}{l}24.20(22.00- \\
26.80)\end{array}$ & & & & \\
\hline \multicolumn{7}{|l|}{$\mathrm{BE}$} \\
\hline $\begin{array}{l}\text { Min. - } \\
\text { Max. }\end{array}$ & $-18.30-4.00$ & $-14.00-3.70$ & \multirow[t]{3}{*}{0.949} & \multirow[t]{3}{*}{$\begin{array}{l}1.004(0.890 \\
-1.133)\end{array}$} & & \\
\hline $\begin{array}{l}\text { Mean } \pm \\
\text { SD. }\end{array}$ & $-2.73 \pm 4.50$ & $-2.66 \pm 4.03$ & & & & \\
\hline $\begin{array}{l}\text { Median } \\
\text { (IQR) }\end{array}$ & $\begin{array}{l}-2.05(-4.40- \\
-0.40)\end{array}$ & $\begin{array}{l}-2.30(-4.70- \\
0.30)\end{array}$ & & & & \\
\hline \multicolumn{7}{|l|}{$\begin{array}{l}\text { Mode Of } \\
\text { Delivery }\end{array}$} \\
\hline Cs & 23 (76.7\%) & 7 (23.3\%) & $<0.001^{*}$ & 1.000 & $<0.001^{*}$ & 1.000 \\
\hline
\end{tabular}




\begin{tabular}{|c|c|c|c|c|c|}
\hline NVD & $7(23.3 \%)$ & $23(76.7 \%)$ & & $\begin{array}{l}10.796 \\
(3.263- \\
35.718)\end{array}$ & $\begin{array}{l}10.796 \\
(3.263- \\
35.718)\end{array}$ \\
\hline \multicolumn{6}{|l|}{$\begin{array}{l}\text { Maternal } \\
\text { history }\end{array}$} \\
\hline Anemia & $17(56.7 \%)$ & $19(63.3 \%)$ & 0.598 & $\begin{array}{l}1.321(0.469 \\
-3.721)\end{array}$ & \\
\hline $\mathrm{PIH}$ & $3(10.0 \%)$ & $5(16.7 \%)$ & 0.452 & $\begin{array}{l}1.800(0.398 \\
-8.323)\end{array}$ & \\
\hline UTI & 10 (33.3\%) & 9 (30.0\%) & 0.781 & $\begin{array}{l}0.857(0.288 \\
-2.547)\end{array}$ & \\
\hline Vaginitis & $13(43.3 \%)$ & $17(56.7 \%)$ & 0.303 & $\begin{array}{l}1.710(0.616 \\
-4.748)\end{array}$ & \\
\hline \multicolumn{6}{|l|}{ HR } \\
\hline $\begin{array}{l}\text { Min. - } \\
\text { Max. }\end{array}$ & $\begin{array}{l}110.00- \\
160.00\end{array}$ & $\begin{array}{l}115.00- \\
160.00\end{array}$ & 0.167 & $\begin{array}{l}1.031(0.987 \\
-1.076)\end{array}$ & \\
\hline $\begin{array}{l}\text { Mean } \pm \\
\text { SD. }\end{array}$ & $135.10 \pm 12.67$ & $139.50 \pm 11.72$ & & & \\
\hline $\begin{array}{l}\text { Median } \\
\text { (IQR) }\end{array}$ & $\begin{array}{l}132.50(125.00 \\
-144.00)\end{array}$ & $\begin{array}{l}141.00(130.00 \\
-149.00)\end{array}$ & & & \\
\hline
\end{tabular}

IQR: Inter quartile range SD: Standard deviation OR: Odd`s ratio

C.I: Confidence interval LL: Lower limit UL: Upper Limit

$p: p$ value for Odd`s ratio for comparing between the studied groups *: Statistically significant at $p \leq 0.05$

Table (4): Comparison between the two studied groups (CS and NVD) according to HR, CRT, cerebral oxygenation parameters (crSO2 and FTOE) and oxygen saturation 
Mode of delivery

Cs

\section{$\mathrm{HR}$ (B/min)}

Min. - Max

Mean \pm SD.

$110-155$

$135 \pm 13$

$134(126-147)$

Median (IQR)

CRT(seconds)

Min. - Max

$2-4$

$2-3$

$2 \pm 0$

Mean \pm SD.

$2 \pm 1$

Median (IQR) $2(2-3)$

$2(2-3)$

NVD

$139 \pm 12$
Test of Sig. p

$119-160$

$t=-1.266$

0.211

$140(130-146)$

Sp02 at $1 \mathrm{~min}$

Min. - Max

$65-89$

$65-89$

$U=352$

0.146

Mean \pm SD.

$73 \pm 7$

$76 \pm 6$

Median (IQR)

$73(68-78)$

$75(72-81)$

Sp02 at 5 min

Min. - Max

$83-95$

$84-99$

$\mathrm{U}=230^{*}$

$0.001^{*}$

Mean \pm SD.

$88 \pm 3$

$91 \pm 4$

Median (IQR)

$88(85-90)$

$92(89-93)$

Sp02 at $10 \mathrm{~min}$

$\begin{array}{lll}\text { Min. }- \text { Max } & 91-100 & 94-99 \\ \text { Mean } \pm \text { SD. } & 95 \pm 2 & 97 \pm 2 \\ \text { Median (IQR) } & 95(94-98) & 97(95-98)\end{array}$

\section{CrSOX 1 min}

Min. - Max.

$15.00-70.00$

$15.00-78.00$

$t=1.260$

0.213

Mean \pm SD.

$44.67 \pm 13.60$

$39.60 \pm 17.33$

Median (IQR)

$45.00(35.00-55.00)$

$39.50(26.00-48.00)$

\section{CrSOX 5 min}

$\begin{array}{llll}\text { Min. }- \text { Max. } & 41.00-86.00 & 52.00-85.00 & U=229.5^{*}\end{array} \quad 0.001^{*}$




\begin{tabular}{|c|c|c|c|c|}
\hline Median (IQR) & $67.00(57.00-74.00)$ & $80.00(67.00-81.00)$ & & \\
\hline \multicolumn{5}{|l|}{ CrSO凶 $10 \mathrm{~min}$} \\
\hline Min. - Max. & $60.00-89.00$ & $67.00-91.00$ & \multirow[t]{3}{*}{$U=219.5^{*}$} & \multirow[t]{3}{*}{$0.001^{*}$} \\
\hline Mean \pm SD & $78.37 \pm 7.39$ & $84.13 \pm 5.81$ & & \\
\hline Median (IQR) & $80.00(74.00-82.00)$ & $85.50(84.00-88.00)$ & & \\
\hline \multicolumn{5}{|c|}{ Rate of rise at 5} \\
\hline Min. - Max & $6-44$ & $2-62$ & \multirow[t]{3}{*}{$t=-3.989^{*}$} & \multirow[t]{3}{*}{$<0.001^{*}$} \\
\hline Mean \pm SD & $22 \pm 9$ & $35 \pm 16$ & & \\
\hline Median (IQR) & $22(17-27)$ & $36(20-46)$ & & \\
\hline \multicolumn{5}{|l|}{ FTOE 1 min } \\
\hline Min. - Max. & $0.0933-0.7692$ & $0.0000-0.7917$ & \multirow[t]{3}{*}{$t=-1.845$} & \multirow[t]{3}{*}{0.070} \\
\hline Mean \pm SD & $0.3972 \pm 0.1584$ & $0.4854 \pm 0.2087$ & & \\
\hline Median (IQR) & $0.3857(0.2877-0.5000)$ & $0.5242(0.3733-0.6286)$ & & \\
\hline \multicolumn{5}{|l|}{ FTOE 5 min } \\
\hline Min. - Max. & $.0753-.5233$ & $0.0581-0.4348$ & \multirow[t]{3}{*}{$U=259.5^{*}$} & \multirow[t]{3}{*}{$0.005^{*}$} \\
\hline Mean \pm SD & $0.2450 \pm 0.1021$ & $0.1791 \pm 0.0901$ & & \\
\hline Median (IQR) & $0.2229(0.1628-0.3294)$ & $0.1390(0.1196-0.2391)$ & & \\
\hline \multicolumn{5}{|l|}{ FTOE $10 \mathrm{~min}$} \\
\hline Min. - Max. & $0.0745-0.3673$ & $0.0625-0.3093$ & \multirow[t]{3}{*}{$U=254.5^{*}$} & \multirow[t]{3}{*}{$0.004^{*}$} \\
\hline Mean \pm SD & $0.1789 \pm 0.0741$ & $0.1299 \pm 0.0591$ & & \\
\hline Median (IQR) & $0.1658(0.1212-0.2143)$ & $0.1224(0.0825-0.1383)$ & & \\
\hline
\end{tabular}

$\mathrm{U}$ : Mann Whitney test $\mathrm{t}$ : Student t-test $\mathrm{p}$ : $\mathrm{p}$-value for comparing between the two studied groups

\section{Figures}



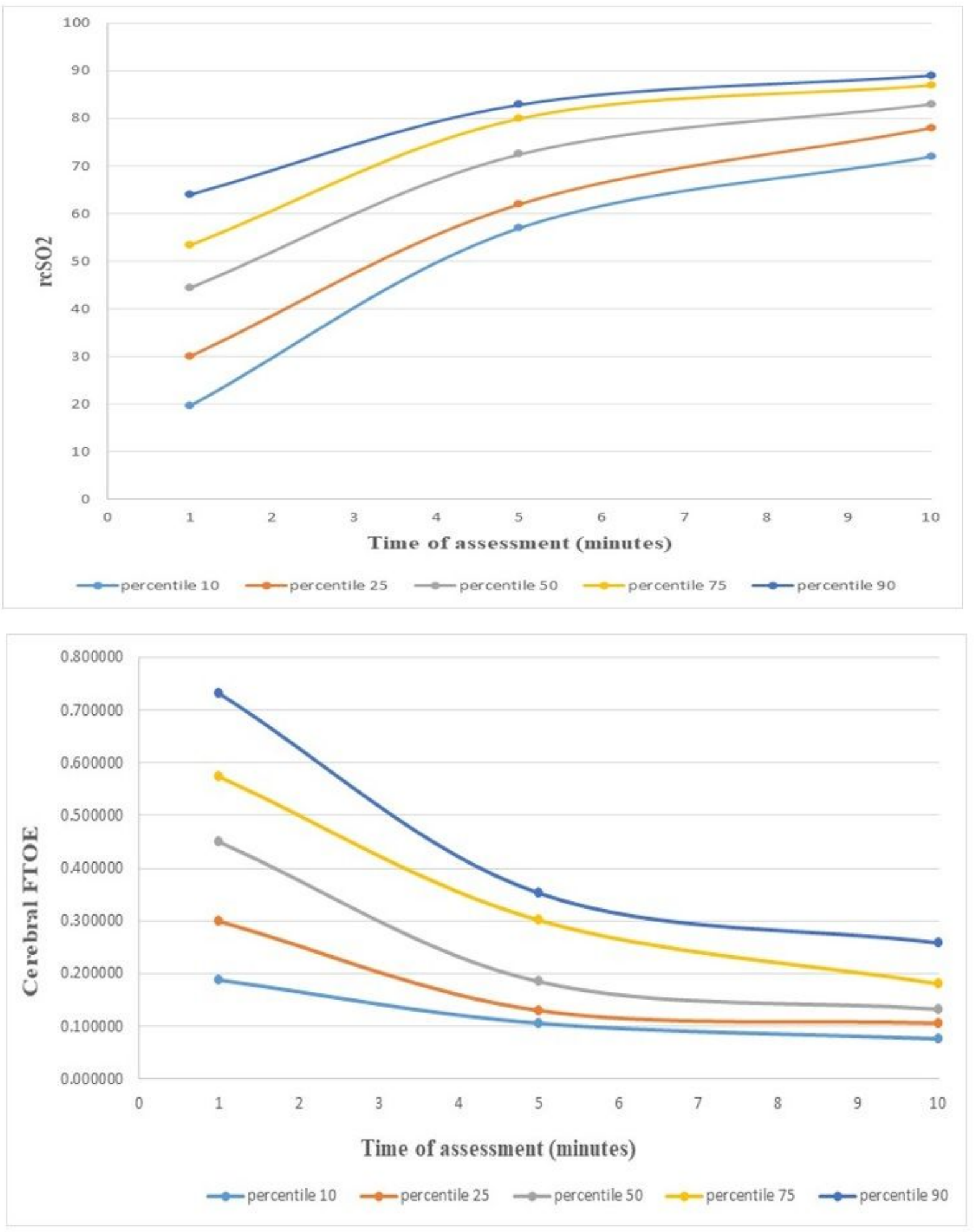

\section{Figure 1}

Centile charts for $\mathrm{CRsO} 2$ and FTEO at 1, 5 and 10 minutes after birth in healthy full term neonates. 

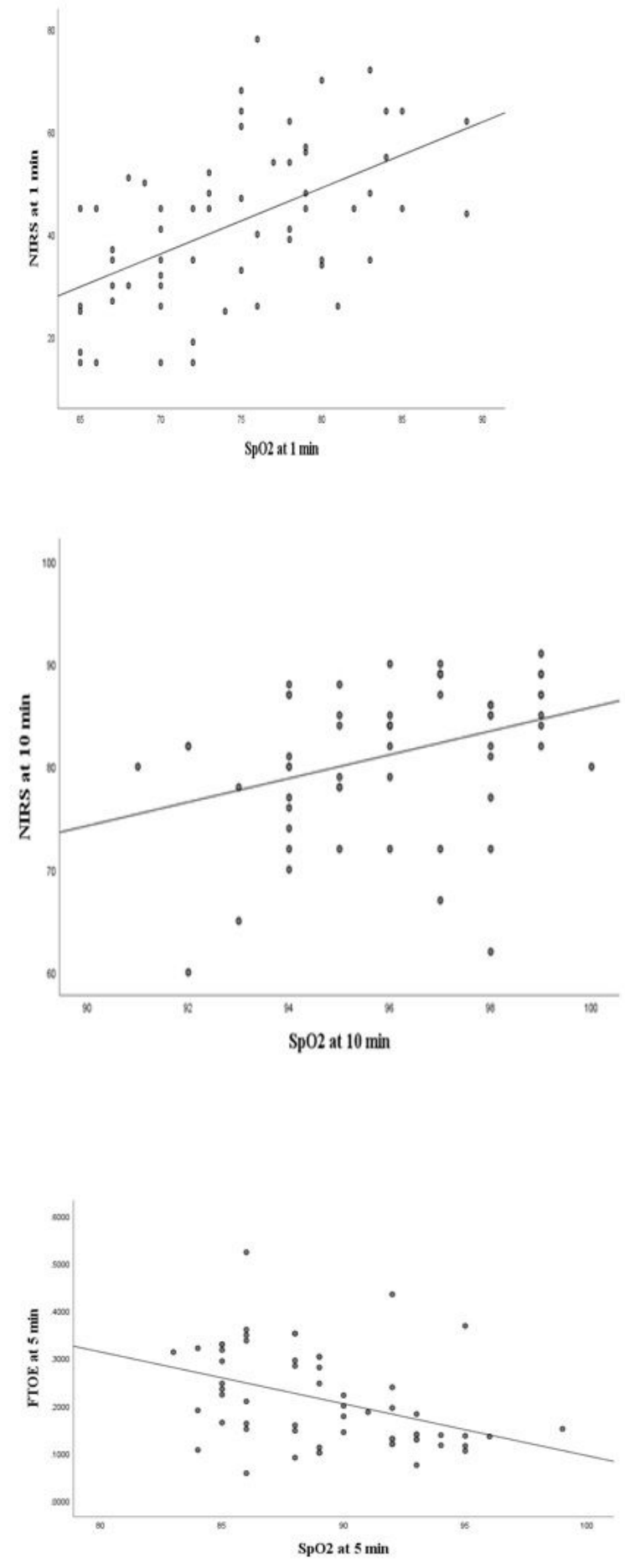
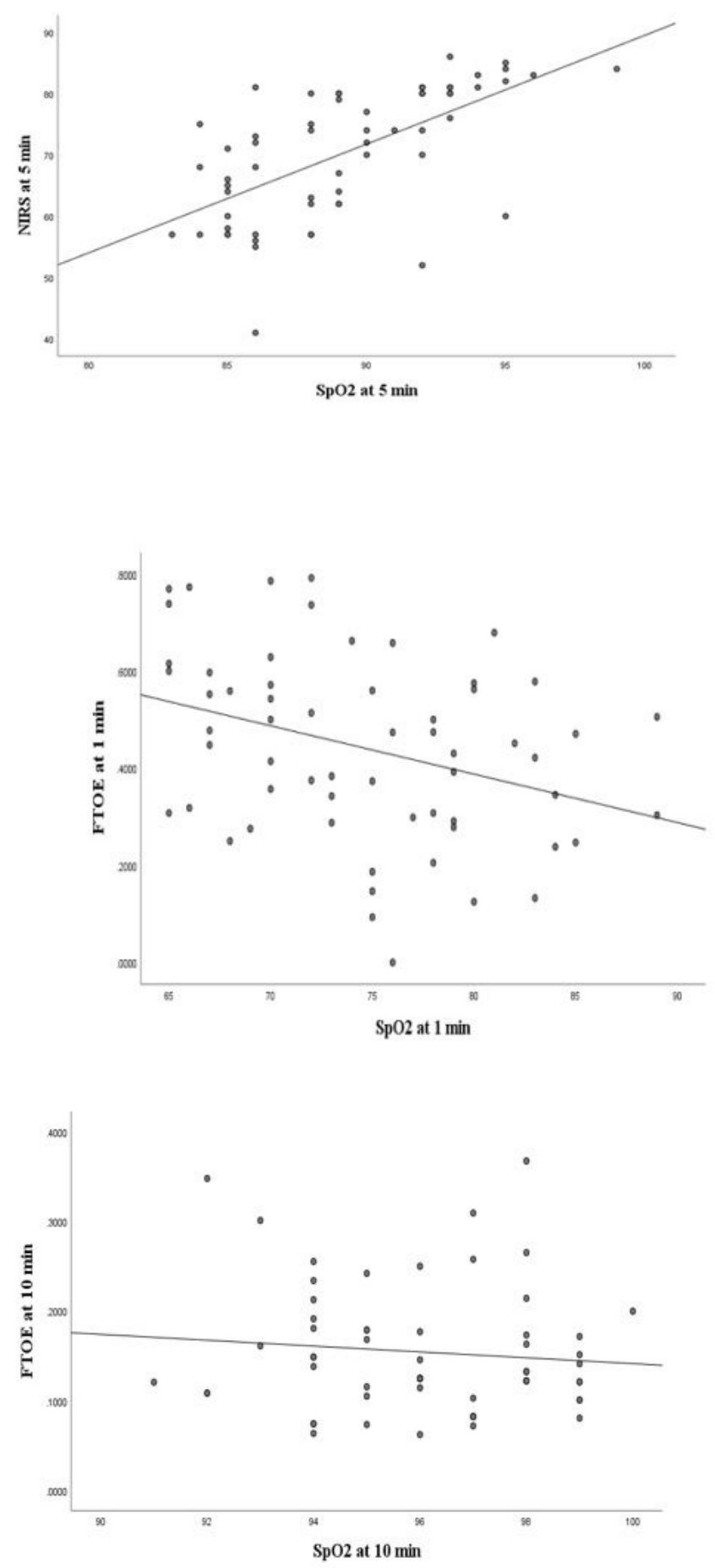

\section{Figure 2}

A; Pearson correlation between cerebral tissue oxygenation and oxygen saturation (pulse oximeter) at 1 minute with $r=0.532\left(p=<0.001^{*}\right)$.

$\mathrm{B}$ and $\mathrm{C}$; Spearman correlation between cerebral tissue oxygenation and oxygen saturation (pulse oximeter) at 5 and 10 minutes with $r 0.673 *(P<0.001 *), r 0.390 *(p=0.002 *)$, respectively. 
D; Pearson correlation between fractional tissue extraction and oxygen saturation (pulse oximeter) at 1 minute $r=-0.342^{*}\left(p=0.008^{*}\right)$

E and F; Spearman correlation between fractional tissue extraction and oxygen saturation (pulse oximeter) at 5 and 10 minutes $r=-0.433^{*}\left(p=0.001^{*}\right), r=-0.076(p=0.563)$, respectively.

*: Statistically significant at $p \leq 0.05$

\section{Supplementary Files}

This is a list of supplementary files associated with this preprint. Click to download.

- suppement.docx 